UDC 616.99:578.426

DOI: $10.21668 /$ health.risk/2020.1.10.eng

\title{
RISK-ORIENTED APPROACH IN ANALYZING EPIDEMIOLOGIC SITUATION WITH INCIDENCE WITH TICK-BORNE ENCEPHALITIS ON ENDEMIC TERRITORIES
}

\author{
A.G. Sergeev ${ }^{1,3}$, V.A. Mishchenko ${ }^{1,4}$, I.P. Bykov ${ }^{1}$, \\ V.V. Romanenko ${ }^{3}$, L.G. Chistyakova ${ }^{2}$, A.V. Alimov ${ }^{1}$ \\ ${ }^{1}$ Yekaterinburg Scientific Research Institute for Viral Infections Studies, a subsidiary of the Vektor State Scientific \\ Center for Virology and Biotechnology, 23 Letnyaya Str., Yekaterinburg, 620030, Russian Federation \\ ${ }^{2}$ Federal Service for Surveillance over Consumer Rights protection and Human Well-being, Sverdlovsk regional \\ office, 3 Otdelnyi lane, Yekaterinburg, 620078, Russian Federation \\ ${ }^{3}$ Ural State Medical University, 3 Repina Str., Yekaterinburg, 62002, Russia Federation \\ ${ }^{4}$ Institute of Plant and Animal Ecology of the Urals Department of Russian Academy of Science URAN, \\ 2028 Marta Str., Yekaterinburg, 620144, Russian Federation
}

Sverdlovsk region is a zone with a strenuous natural-anthropogenic focus of virus tick-borne encephalitis (TBE). Incidence with the disease has decreased by 5 times over the last 20 years due to mass vaccination among population. Since 2015 incidence with TBE has remained steady at fewer than 3 cases per 100,000 people. However, over the last 10 years incidence with TBE has been decreasing at a significantly slower rate due to a considerable growth in number of immune people (from $68 \%$ in 2007 to $84.99 \%$ in 2018). Analysis revealed that probability of the disease after a person had been bitten by a tick was quite different on different territories in the region.

Our research goal was to develop a procedure for ranking administrative territories as per risks of clinical TBE occurrence among people bitten by ticks.

We took a number of people bitten by ticks per one TBE case as our risk parameter. Our analysis revealed that average regional risk reached its maximum values (1:40-1:50) in years prior to implementation of mass vaccination against TBE. As a number of immune people grew, risk fell by 6 times (just 1 TBE case per 319 bitten people in 2018). Average regional risk was taken as to be equal to 1 . We ranked administrative territories as per their risk index values (a ratio of a territorial risk to average regional one).

We showed that ranking of TBE-endemic territories as per their risk index allowed implementing a differentiated approach to planning and organizing efficient prevention.

Key words: virus tick-borne encephalitis, epidemic process, incidence, mass vaccination, people bitten by ticks, disease risk index, risk index, ranking of endemic territories.

Over the last 50 years there have been considerable changes in epidemiology of virus tick-borne encephalitis (TBE) due to occurrence of anthropogenic foci around cities located on endemic territories and urban popula-

tion becoming involved into the epidemic process as a major risk group [1-4]. It resulted in changes in vaccination strategies involving implementation of extended vaccinal prevention up to mass immunization among popula-

(c) Sergeev A.G., Mishchenko V.A., Bykov I.P., Romanenko V.V., Chistyakova L.G., Alimov A.V., 2020

Alexandr G. Sergeev - Doctor of Medical Sciences, Professor, Head of Microbiology, Virology and Immunology Department, Head of the Department for Indication and Diagnosis of Viral Infections, Chief Researcher (e-mail: aldr131250@yandex.ru; tel.: +7 (343) 214-86-95; tel.: +7 (343) 261-99-47; ORCID: https://orcid.org/0000-0002-5784-8673).

Vladimir A. Mishchenko - Researcher, Acting Head of the Laboratory for Vector-borne Viral Infections and Tickborne Encephalitis, The First Category Engineer at the Evolutionary Ecology Laboratory (e-mail: innamoramento23@yandex.ru; tel.:+7 (343) 261-99-47; ORCID: https://orcid.org/0000-0003-4280-283X).

Ivan P. Bykov - Candidate of Medical Sciences, Senior Researcher at theLaboratory for Vector-borne Viral Infections and Tick-borne Encephalitis (e-mail: i.p.bykov@mail.ru; tel.: +7 (343) 261-99-47; ORCID: https://orcid.org/0000-0002-5157-646X).

Viktor V. Romanenko - Doctor of Medical Sciences, Associate Professor at the Epidemiology Department (e-mail: romanenko.v47@gmail.com; tel.: +7 (343) 261-99-47; ORCID: https://orcid.org/0000-0002-9977-8845).

Larisa G. Chistyakova - Chief Expert at the Department for Epidemiologic Surveillance (e-mail: mail@66.rospotrebnadzor.ru; tel.: +7 (343) 374-13-79; ORCID: https://orcid.org/0000-0003-2376-1761).

Alexandr V. Alimov - Candidate of Medical Sciences, Director (e-mail: virus@eniivi.ru; tel.: +7 (343) 261-99-47; ORCID: https://orcid.org/0000-0003-0511-9409). 
tion taking into account risks of contagion with TBE virus on this or that territory; those risks manifested themselves via levels of morbidity [5-8]. Impressing results of mass preventive vaccination against TBE among population were first achieved in Austria; when more than $80 \%$ population were vaccinated against TBE, it allowed reducing morbidity by 15 times [9-11].

In the Russian Federation risks of TBE contagion among population differ significantly both on TBE-endemic regions and on specific territories within those regions [12]. The Urals Federal District is a region where morbidity with TBE is rather high; Sverdlovsk region is included into this Federal District. The whole territory of the region is a zone with intense natural-anthropogenic focus of tick-borne infections, virus tick-borne encephalitis (TBE) being one of the most significant [13]. Over more than 70 years of observation (1944-2018) there have been significant cyclic fluctuations in morbidity with TBE detected in Sverdlovsk region [14]. These cycles occur due to biological factors (periodical changes in numbers of natural tick carriers); weather and climatic factors (air temperature and humidity during a period when ticks are most active); and socioeconomic factors as well [15-17].

From 1956 to 1999 rises and falls in morbidity took their turns with 3-4 year intervals and their turns coincided with periods during which ticks were most active. After 1999 mass immunization among population was implemented, and dynamics of morbidity changed. Thus, from 1999 to 2011, duration of cycles involving rises and falls in morbidity with TBE taking their turns grew to 6 years; from 2012 to 2018 there was a clear trend in morbidity stabilizing at a low level with insignificant annual fluctuations (2.4-3.6 per 100 thousand people) [18].

A considerable amount of people who get infected and fall sick with TBE during annual rises in morbidity with $\mathrm{TBE}$ in spring and summer are those who haven't been vaccinated or their vaccination hasn't been completed. Over the last 25 years picks in morbid- ity with TBE were detected in 1993, 1996, 1999, 2005, and 2011 (24.0, 42.9, 19.3, 10.1, and 6.1 per 100 thousand people accordingly).

Morbidity with TBE among population living on endemic territories is well-known to directly depend on ticks being most active in spring and summer. There is a regular dependence between a number of people applying for medical aid due to tick bites and morbidity [12].

Over the last 20 years the epidemiologic service of the Regional Rospotrebnadzor Office in Sverdlovsk region has been actively performing targeted prevention activities and it has allowed achieving substantial results as regard reducing morbidity with TBE [19].

Since 1996 mass vaccination against TBE has been implemented within the regional prevention program; due to it starting from 2000 there has been a persistent descending trend in morbidity [20]. Since 2015 morbidity with TBE has remained insignificant, namely lower than 3 cases per 100 thousand people. In 2017 a share of regional population vaccinated against TBE reached $87.4 \%$. However, even now TBE cases are registered on $80 \%$ of all administrative territories in the region. Average long-term morbidity (ALTM) with TBE amounts to 2.85 per 100 thousand people and it is by 1.65 times higher than on average in the country (1.72 per 100 thousand people). Annually up to $5 \%$ of all people sick with TBE are those who have completed their anti-TBE vaccination. Having analyzed the structure of TBE clinical forms among vaccinated and non-vaccinated people, experts revealed that a specific weight of focal forms was by several times lower among vaccinated people than among non-vaccinated ones, and in some years (2011-2013) $100 \%$ of vaccinated people had only fever TBE. Nevertheless, lethality among people suffering from TBE has been varying from 0.6 to $2.7 \%$ over a long period of time.

We analyzed dynamics of the TBE epidemic process in Sverdlovsk region over the last 20 years; the analysis revealed that mass vaccination among population that started in 1998 allowed reducing morbidity with TBE in 
Sverdlovsk region by more than 8 times by 2018 (down to 2.35 per 100 thousand people). At the same time, morbidity on 11 administrative territories was still 1.5-2 times higher than on average in the region; it was more than 2 times higher on 6 territories.

In $201884.99 \%$ people living in Sverdlovsk region were vaccinated against TBE. On half of administrative territories the figure was even higher as more than $90 \%$ people living there were vaccinated. However, over the last 10 years, in spite of a considerable growth in a share of vaccinated population (from $68 \%$ in 2007 to $84.99 \%$ in 2017), reduction in morbidity with TBE has slowed down considerably.

Except from 1996 and 2011, when there was a drastic rise in activity of ticks $(2,027.8$ and 1,325.7 bitten people per 100 thousand accordingly), over 1995-2018 a number of people bitten by ticks varied from 489.7 (the minimum in 2002) to 983 (the maximum in 2015) per 100 thousand people. A square where annual acaricide treatments took place increased by 10 times from 2000 to 2018 (from 969 hectares in 2000 to 9,498 hectares in 2018); however, it didn't result in any decrease in number of people bitten by ticks (565 and 749 per 100 thousand people in 2000 and 2018 accordingly). It indicates that a system of planning and organizing acaricide treatments on endemic territories needs substantial revising and adjusting.

A share of vaccinated people in Yekaterinburg $(88.88 \%)$ is higher than on average in the region $(84.99 \%)$. At the same time morbidity with TBE among population living in Yekaterinburg is annually higher than on average in the region (average long-term morbidity is 3.94 and 2.85 per 100 thousand people accordingly). About $30 \%$ of the overall region population live in Yekaterinburg. The Yekaterinburg city square amounts to $0.6 \%$ of the overall region territory, but people living in Yekaterinburg account for about $50 \%$ of all patients with TBE (average long-term morbidity is equal to 55 out of $118 \mathrm{TBE}$ cases in the region). The above data indicate it is necessary to analyze why people living in Yekaterinburg are not efficiently protected from TBE even though there is annual mass vaccination.

Comparative analysis performed with maps that showed how territories in the region were ranked as per such parameters as morbidity with TBE and average numbers of ticks revealed that morbidity with TBE among population living on this or that territory didn't correlate with high, average, or low numbers of ticks on it in most cases. Thus, zones with high quantities of ticks were located on the south and west-south of the region whereas terrorizes where morbidity with TBE among population was high were located along the meridian from north to south in sub-zones of mid-latitude and southern taiga. The analysis also revealed that a number of people bitten by ticks didn't correspond to morbidity with TBE on most territories, that is, a probability (risk) that a manifested disease could occur after a tick bite was different for population living on different territories.

Our research goal was to analyze longterm dynamics of the TBE epidemic process in Sverdlovsk region and, basing on the analysis results, to work out a procedure for ranking administrative territories as per a risk of a manifest disease among people bitten by ticks.

Data and methods. We took necessary data from the State Statistical Report Form No. 2 "Data on infectious and parasitic diseases" filled in by the Rospotrebnadzor's Federal center for Hygiene and Epidemiology, Sverdlovsk regional office. Data on a number of people bitten by ticks and a share of population who got vaccinated against TBE were obtained from annual reports on sanitary-epidemiologic welfare of the population issued by the Rospotrebnadzor Sverdlovsk Regional Office.

We took probability of a manifest TBE case after a tick bite as our risk parameter. We calculated average regional risks of manifest TBE among bitten people and those for specific administrative territories via finding a ratio between a number of bitten people and morbidity with TBE per 100 thousand people on a given territory.

We calculated risk index via determining a ratio between a risk calculated for an admin- 
istrative territory and the average regional risk which was taken as being equal to 1 .

Results and discussion. Collective immunity among population living on a given territory, share of infected ticks in a local tick population, and virulence of circulating TBE strains are basic factors that determine how high a risk of TBE occurrence is after exposure. This parameter is integral as it allows objectively assessing whether population living on a given territory is well-protected. Therefore, determining a risk of TBE occurrence in people who were bitten by ticks in different years and on different territories provides additional data for epidemiologic analysis and efficiency assessment for specific and non-specific prevention of the disease.

We can examine dynamics in such risks taking into account mass vaccination against TBE on the example of Sverdlovsk region. Figure 1 shows long-term dynamics of morbidity with TBE and risks of the diseases occurrence in people bitten by ticks.

As we can see from the data given above, risk was on average equal to $1 \mathrm{TBE}$ case per 50 bitten people prior to mass vaccination and during first years after it has been started (1995-2002). This value is well in line with results obtained via monitoring over shares of infected ticks in populations in Sverdlovsk region which were on average equal to $2 \%$.

In 2018 risk decreased by 7.6 times in comparison with the period prior to vaccination (from 1:42 to 1:319). Over the same period of time morbidity went down by 5 times (average long-term morbidity being equal to 14.6 and 2.85 per 100 thousand people accordingly).

Figure 2 shows long-term dynamics of risks taking into account growing shares of people who got vaccinated against TBE in the region.

As we can see from the data given above, after $60 \%$ of population got vaccinated, risk of the diseases started to fall dramatically. However, as more than $70 \%$ of population got vaccinated in 2008, it leveled off at 1:200-1:250 (there were no statistically significant discrepancies, $p>0.05$ ). Therefore, an increase in a share of population who got vaccinated over the last 10 years from $73 \%$ to $85 \%$ didn't have any significant influence on risk of TBE occurrence after a tick bite. But still, there was a persistent descending trend in morbidity. From 2008 to 2014 morbidity with TBE varied from 6.1 to 3.4 per 100 thousand people, and starting from 2015 it stabilized at fewer than 3 cases per 100 thousand people (Figure 1).

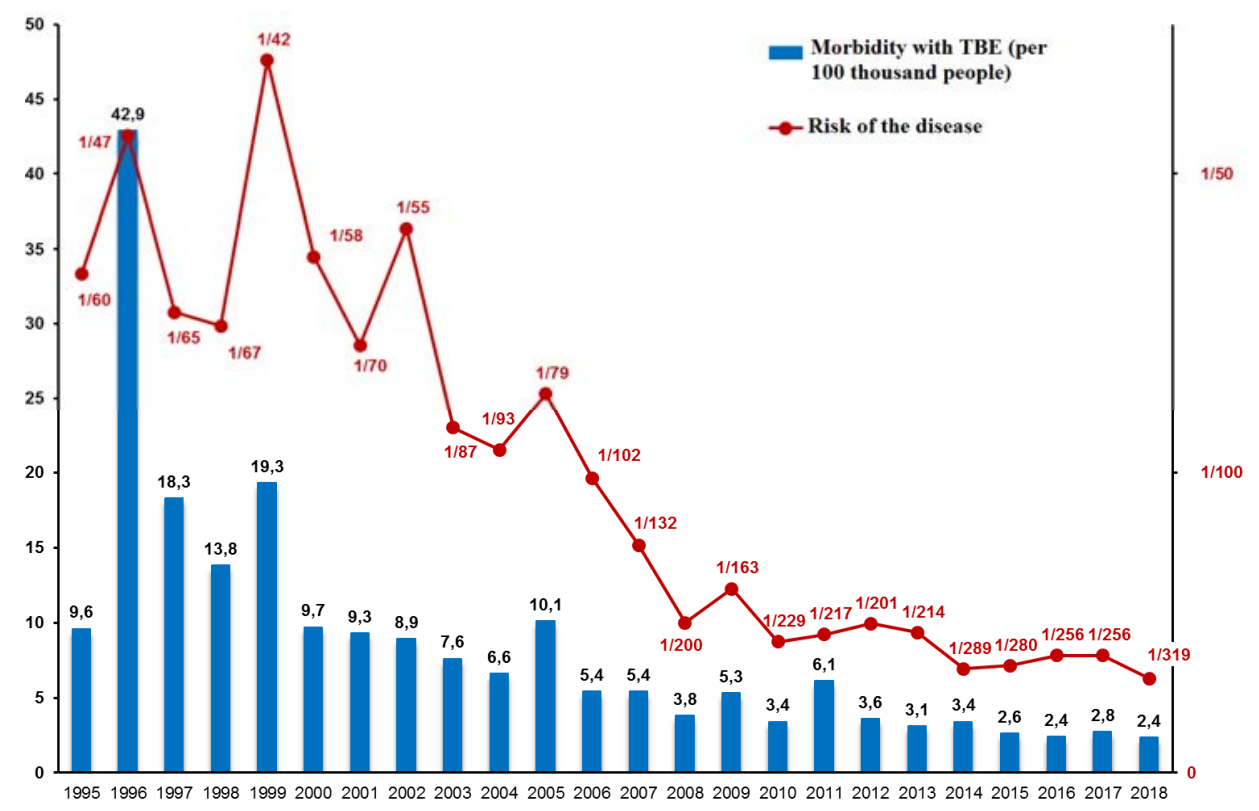

Figure 1. Long-term dynamics of morbidity with virus tick-borne encephalitis in Sverdlovsk region (per 100 thousand people) and risk of the disease (number of bitten people per 1 disease case) 


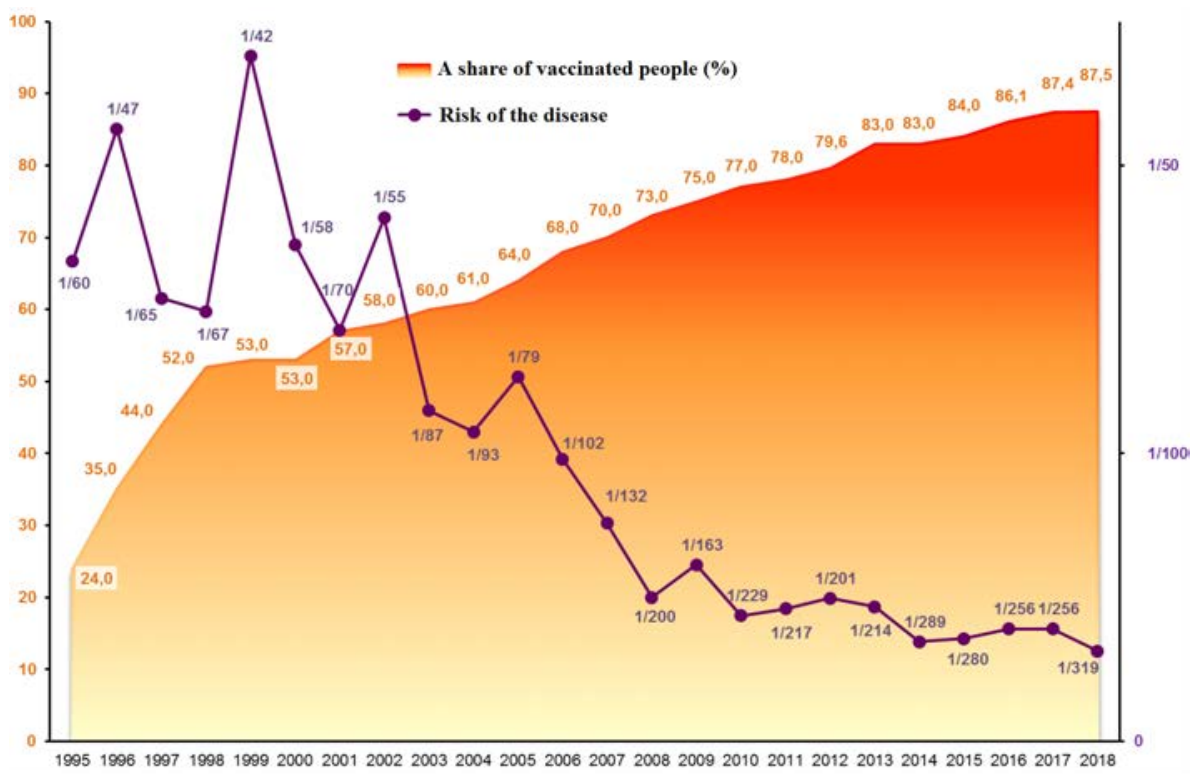

Figure 2. A share of people living in Sverdlovsk region who got vaccinated against virus tick-borne encephalitis and risk of the disease (number of bitten people per 1 disease case)

Figure 3 shows long-term dynamics of a number of bitten people and the risk of TBE occurrence among them.

As we can see from the given data, risk didn't change significantly from 2008 to 2018 even though there were considerable fluctuations in numbers of people bitten by ticks. It indicates there is no correlation between a number of people bitten by ticks and risks of TBE among those who were bitten.

Risk-oriented approach to analyzing epidemiologic situation with TBE allows spotting out administrative territories where there is certain divergence in parameters related to a number of bitten people and morbidity with TBE, in particular:

- territories where a number of bitten people is high but there are no TBE cases;

- territories where a number of bitten people is high but morbidity with TBE is close to average regional values;

- territories where morbidity is high but a number of bitten people is close to average regional values.

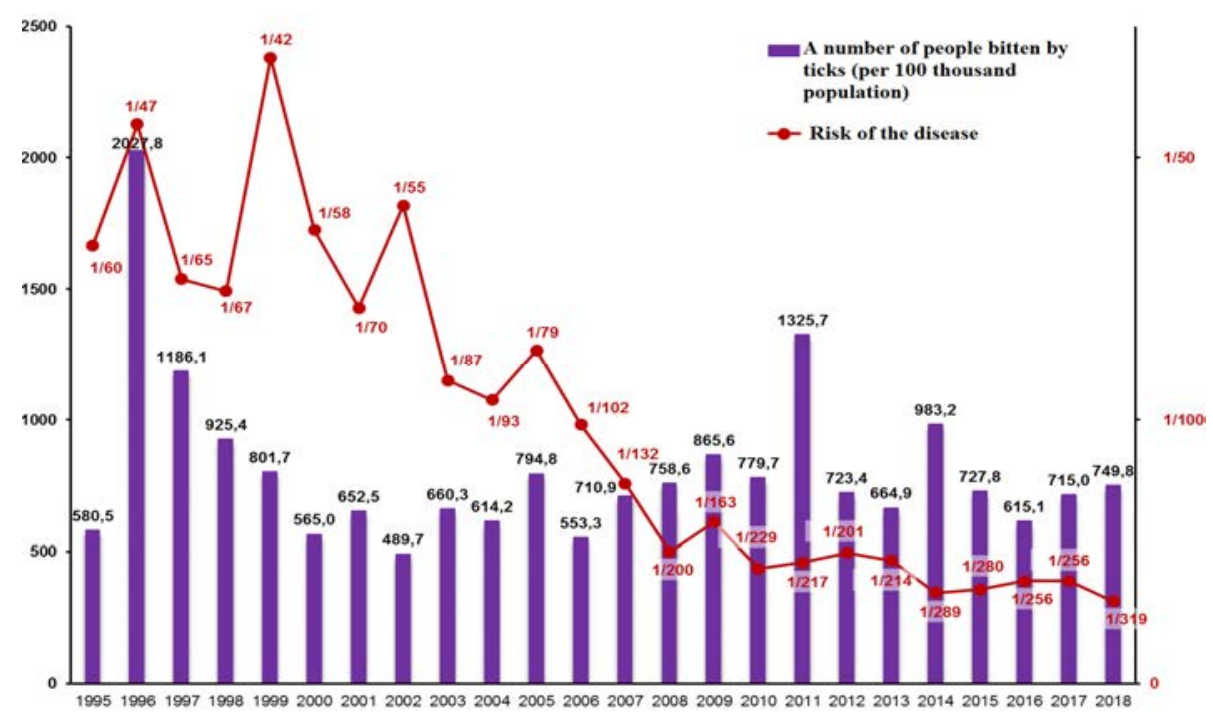

Figure 3. Long-term dynamics of a number of bitten people per 100 thousand people living in Sverdlovsk and risk of virus tick-borne encephalitis among them 
Table 1

Parameters showing numbers of people bitten by ticks and morbidity with virus tick-borne encephalitis in specific municipal districts in Sverdlovsk region in 2017

\begin{tabular}{|l|c|c|c|c|}
\hline \multicolumn{1}{|c|}{ Territory } & $\begin{array}{c}\text { A number of people } \\
\text { bitten by ticks } \\
(\% 0000)\end{array}$ & $\begin{array}{c}\text { A ratio of a number of } \\
\text { bitten on a specific territory } \\
\text { to average regional one }\end{array}$ & $\begin{array}{c}\text { Morbidity } \\
\text { with TBE } \\
(\% 0000)\end{array}$ & $\begin{array}{c}\text { A ratio to average } \\
\text { regional morbidity } \\
\text { with TBE }\end{array}$ \\
\hline Sverdlovsk region & 715.00 & 1.00 & 2.75 & 1.00 \\
\hline Asbest district & $1,528.50$ & 2.10 & 1.50 & 0.50 \\
\hline Revda district & 740.40 & 1.04 & 4.60 & 1.67 \\
\hline Polevsk district & 855.60 & 1.20 & 7.10 & 2.60 \\
\hline
\end{tabular}

Table 2

Risk of TBE occurrence among people bitten by ticks and a share of vaccinated people in specific municipal districts in Sverdlovsk region in 2017

\begin{tabular}{|l|c|c|c|}
\hline \multicolumn{1}{|c|}{ Territory } & $\begin{array}{c}\text { Risk of manifest TBE } \\
\text { among bitten people }\end{array}$ & Risk index & $\begin{array}{c}\text { A share of people } \\
\text { vaccinated against TBE (\%) }\end{array}$ \\
\hline Sverdlovsk region & $1: 260$ & 1.0 & 87.4 \\
\hline Asbest district & $1: 1,019$ & 0.3 & 96.3 \\
\hline Revda district & $1: 160.9$ & 1.6 & 86.5 \\
\hline Polevsk district & $1: 120.5$ & 2.2 & 73.1 \\
\hline
\end{tabular}

The procedure includes:

1. Calculating average regional risk of TBE occurrence and risks for specific administrative territories via finding a quotient from dividing morbidity with TBE per 100 thousand people by a number of people bitten by ticks on a given territory.

2. Calculating risk index via calculating a ratio between risk for a given administrative territory and average regional risk that is taken as being equal to 1 .

3. Ranking administrative territories as per risk index:

- high risk (index is $\geq 1.3$ );

- moderate risk (index is $0.70<1.0<1.3$ );

- low risk (index is $\leq 0.70$ ).

Should a territory be ranked as having high risk index, it is advisable to pay special attention to analyzing volumes and quality of vaccinal prevention, urgent immune TBE prevention, and examining collective immunity among population on such a territory.

In case risk is moderate (morbidity with TBE is equal to average regional one or higher and a number of bitten people is high), it is necessary to analyze volumes and efficiency of acaricide treatments as well as efficiency of sanitary-educational activities among population aimed at commutating how to keep safe in the forest and prevent tick bites.

Tables 1 and 2 contain an example on how to present and analyze data on risk-oriented approach to ranking territories that are endemic as per TBE.

As we can see from data given in the tables, a probability of catching TBE among people bitten by ticks can be different on different territories where a share of people who got vaccinated against TBE is also different. Thus, people living in Asbest district run the lowest risks of TBE even though a number of people bitten by ticks on that territory was 2.1 times higher than on average in the region, but still morbidity with TBE amounted to 1.5 per 100 thousand people and it was 1.8 times lower than on average in the region $(2.75$ per 100 thousand people). Therefore, a risk of manifest TBE occurrence was 3.3 times lower in Asbest district than in the region as a whole and it indicates that a high share of vaccinated 
people $(96.3 \%)$ exerts significant influence on morbidity with TBE; on the contrary, there is no correlation between a number of people bitten by ticks and a number of TBE cases.

It means that it is advisable to implement specific and non-specific prevention activities on the territory; they should be scheduled and focus on selective immunization of risk groups with the highest risks of manifest TBE occurrence, namely, those age cohorts where a share of vaccinated people hasn't reached its target level $(95 \%)$. It is also necessary to pay special attention to assessing quality of performed acaricide treatments and sanitary-educational activities aimed at informing people about the necessity of timely immunization against TBE and rules of safe behavior in the forest that will protect them from tick bites.

In Revda district in 2017 morbidity with TBE amounted to 4.6 per 100 thousand people and it was 2 times higher than on average in the region although numbers of people bitten by ticks were relatively similar, 740.4 on the territory against 715.0 per 100 thousand people on average in the region. At the same time risk of manifest TBE occurrence among people bitten by ticks was 1.6 times high in Revda district than on average in the region. A share of people who got vaccinated against TBE was quite similar in Revda district to that in the region, $86.5 \%$ against $87.4 \%$. In this case, it is clear that not enough people have been vaccinated in Revda district and it is advisable to take additional efforts aimed at scheduled immunization among children combined with immunization among adults who haven't been vaccinated in due time; it is also necessary to perform stricter control over timely revaccination among vaccinated people and to examine intensity of collective immunity against TBE.

In Polevsk district in 2017 there was a high risk of manifest TBE, 2.2 times higher than on average in the region; also a number of people bitten by ticks was by $20 \%$ higher, and morbidity with TBE was 2.6 times higher against on average in the region. Only $73.1 \%$ people living on the territory were vaccinated against TBE. All the above indicates that a low share of vaccinated people can't have any significant influence on a further decrease in morbidity with TBE in Polevsk district as the latter directly depends on a number of people bitten by ticks.

Therefore, a leading prevention activity in Polevsk district should be scheduled immunization among children accomplished within the Regional prevention vaccination schedule and mass immunization among those adults who haven't been vaccinated in due time. Not less than $95 \%$ people should be vaccinated against TBE in all age cohorts.

To sum up all the above stated, we can conclude that a risk parameter gives an objective assessment of new TBE cases probability among population living on a specific territory and allows choosing priority prevention activities (specific or non-specific prevention) aimed at decreasing morbidity with TBE.

\section{Conclusions:}

1. Determining post-exposure risk of TBE occurrence on different territories (a number of people bitten by ticks per 1 TBE case) allows obtaining additional significant data for epidemiologic analysis and planning efficient prevention activities.

2. Ranking territories that are endemic as per TBE as per risk parameter allows objectively assessing whether population living there is well protected and implementing differentiated approach to planning and organizing efficient prevention activities.

Funding. The research was not granted any sponsor support.

Conflict of interests. The authors declare there is no any conflict of interests.

\section{References}

1. Korenberg E.I., Pomelova V.G., Osin N.S. Prirodno-ochagovye infektsii, peredayushchiesya iksodovymi kleshchami [Natural foci infections transferred by ticks]. Moscow, Kommentarii Publ., 2013, 464 p. (in Russian). 
2. Alekseev A.N., Dubinina E.V., Yushkova O.Yu. Funktsionirovanie parazitarnoi sistemy «kleshchvozbuditeli» v usloviyakh usilivayushchegosya antropogennogo protsessa ["Ticks-infectious agents" parasitic system and its functioning under intensifying anthropogenic processes]. Sankt-Peterburg Publ., 2008, 146 p. (in Russian).

3. Verigina E.V., Simonova E.G., Chernyavskaya O.P., Pakskina N.D. Contemporary Epidemiological Situation and Some of the Monitoring Results for Tick-Borne Encephalitis Virus. Epidemiologiya $i$ vaktsinoprofilaktika, 2013, vol. 71, no. 4, pp. 14-20 (in Russian).

4. Zavadska D., Odzelevica Z., Karelis G., Liepina L., Litauniece Z.A., Bormane A., Lucenko I., Perevoscikovs J. [et al.]. Tick-borne encephalitis: A 43-year summary of epidemiological and clinical data from Latvia (1973 to 2016). PLoS ONE, 2018, vol. 13, no. 11, pp. e0204844. DOI: 10.1371/journal.pone. 0204844

5. Korenberg E.I. Infections Transmitted by Ticks in the Forest Area and the Strategy of Prevention: Changing of Priorities. Epidemiologiya i vaktsinoprofilaktika, 2013, vol. 72, no. 5, pp. 7-17 (in Russian).

6. Leonova G.N. Vaccinal prevention of tick-borne encephalitis in the past, present and future. Byulleten' Sibirskogo otdeleniya Rossiiskoi akademii meditsinskikh nauk, 2011, vol. 31, no. 4, pp. 79-85 (in Russian).

7. L'vov D.K., Zlobin V.I. Prevention of tick-borne encephalitis at the present stage: Strategy and tactics. Voprosy virusologii, 2007, vol. 52, no. 5, pp. 26-30 (in Russian).

8. Vaccines against tick-borne encephalitis: WHO position paper - Recommendations. Vaccine, 2011, vol. 29, no. 48, pp. 8769-8770. DOI: 10.1016/j.vaccine.2011.07.024

9. Beauté J., Spiteri G., Warns-Petit E., Zeller H. Tick-borne encephalitis in Europe, 2012 to 2016. Eurosurveillance, 2016, vol. 23, no. 45, pp. 1-9. DOI: 10.2807/1560-7917.ES.2018.23.45.1800201

10. Epidemiological situation of tick-borne encephalitis in the European Union and European Free Trade Association countries. Stockholm, European Centre for Disease Prevention and Control (ECDC), 2012, 54 p.

11. Riccardi N., Antonello R.M., Luzzati R., Zajkowska J., Di Bella S., Giacobbe D.R. Tick-borne encephalitis in Europe: a brief update on epidemiology, diagnosis, prevention, and treatment. European Journal of Internal Medicine, 2019, vol. 62, pp. 1-6. DOI: 10.1016/j.ejim.2019.01.004

12. Noskov A.K., Il'in V.P., Andaev E.I., Pakskina N.D., Verigina E.V., Balakhonov S.V. Morbidity Rates as Regards Tick-Borne Viral Encephalitis in the Russian Federation and across Federal Districts in 2009-2013. Epidemiological Situation in 2014 and Prognosis for 2015. Problemy osobo opasnykh infektsii, 2015, no. 1, pp. 46-50 (in Russian).

13. Glinskikh N.P., Kokorev V.S., Patsuk N.V., Kuchkova E.V., Gogoleva O.Yu. Kleshchevoi entsefalit: epidemiologiya, klinika, diagnostika, profilaktika: monografiya [Tick-borne encephalitis: epidemiology, clinical course, diagnostics, and prevention: a monograph]. Ekaterinburg, Izdatel'stvo AMB Publ., 2006, 164 p. (in Russian).

14. Kotel'nikova G.M., Ponomarev D.N. K epidemiologicheskoi i zooparazitologicheskoi kharakteristike ochaga kleshchevogo entsefalita $\mathrm{v}$ raione gornogo Urala [On epidemiologic and zooparasitological parameters of a tick-borne encephalitis focus in the mountain Urals].Sverdlovsk, SredneUral'skoe knizhnoe izdatel'stvo Publ., 1969, pp. 65-67 (in Russian).

15. Berikov V.B., Lbov G.S., Polyakova G.L., Bakhvalova V.N., Panov V.V., Shchuchinova L.D., Gladkii P.A., Korotkov Yu.S. [et al.]. Analysis of Factors Influencing the Incidence of Tick-Borne Encephalitis, Using Logical-and-Probabilistic and Correlation-Regression Models. Epidemiologiya i vaktsinoprofilaktika, 2011, vol. 61, no. 6, pp. 25-34 (in Russian).

16. Yasyukevich V.V., Titkina S.N., Popov I.O., Davidovich E.A., Yasyukevich N.V. Climatedependant diseases and arthropod vectors: possible influence of climate change observed in Russia. Problemy ekologicheskogo monitoring i modelirovaniya ekosistem, 2013, no. 25, pp. 314-359 (in Russian).

17. Süss J., Klaus Ch., Gerstengarbe F.-W., WernerP.C. What Makes Ticks Tick? Climate Change, Ticks, and Tick-Borne Diseases. Journal of Travel Medicine, 2008, vol. 15, no. 1, pp. 39-45. DOI: 10.1111/j.1708-8305.2007.00176.x 
18. Mishchenko V.A., Ladygin O.V., Bykov I.P., Zakharova J.A., Sergeev A.G., Kshnyasev I.A. Morbidity with tick-borne viral encephalitis in some regions in Uralskiy Federal District with predictive estimate of short-term epidemiologic situation. Health Risk Analysis, 2019, no. 1, pp. 68-77 (in Russian). DOI: $10.21668 /$ health.risk/2019.1.07.eng

19. Romanenko V.V., Kilyachina A.S., Esyunina M.S., Ankudinova A.V., Pimenova T.A. Effektivnost' programmy massovoi immunoprofilaktiki kleshchevogo entsefalita [Mass immune prevention of tick-borne encephalitis and its efficiency]. Biopreparaty. Profilaktika, diagnostika, lechenie, 2008, vol. 30, no. 2, pp. 9-14 (in Russian).

20. Esyunina M.S., Romanenko V.V., Kilyachina A.S. Duration of post-vaccination immunity against tick-borne encephalitis following booster doses. Trudy Instituta poliomielita $i$ virusnykh entsefalitov imeni M.P. Chumakova RAMN. Meditsinskaya virusologiya, 2015, vol. 29, no. 2, pp. 132 (in Russian).

Sergeev A.G., Mishchenko V.A., Bykov I.P., Romanenko V.V., Chistyakova L.G., Alimov A.V. Riskoriented approach in analyzing epidemiologic situation with incidence with tick-borne encephalitis on endemic territories. Health Risk Analysis, 2020, no. 1, pp. 92-100. DOI: 10.21668/health.risk/2020.1.10.eng

Received: 24.09 .2019

Accepted: 03.02.2020

Published: 30.03 .2020 